\title{
NEW VOICES IN LABOUR STUDIES: EMERGING PERSPECTIVES ON WORKERS AND WORKPLACES
}

Stephanie Ross

Assistant Professor,

Work and Labour Studies Program,

Department of Social Science,

York University,

Toronto, Ontario, Canada
Jenny Carson

Assistant Professor, Department of History,

Ryerson University, Toronto, Ontario, Canada

$\mathrm{N}$ ews of neoliberalism's demise in 2008 was unquestionably premature. As both ideology and policy, it continues to maintain a fast hold on economic and political elites as we stagger through an ever-lengthening period of austerity. The crux of neoliberalism, however, has been to shelter the wealthy from the risks of the free market while subjecting the working classes to its discipline and the costs of its failures. The economic and social consequences for working-class people, their communities and organizations have been disastrous.

The past several years have not been good for the working class, and 2011 has been no exception. The push at Toronto City Hall to slash and privatize core public services, recast as "gravy" by those who would eliminate them, the nearly unprecedented assault on public sector unions across North America and Europe, a legal landscape which continues to be shaped largely by the Harris-era Ontario Labour Relations Act of 1995, and the federal Conservatives' anti-union disposition have undermined worker power locally and nationally. The summer of 2011 alone saw workers' bargaining and strike power undermined by Ontario employers' use of replacement workers at places such as Infinity Rubber in Mississauga and the federal Parliament's premature use of back-to work legislation against workers at Canada Post and Air Canada. Conversely, strikes and lockouts in the private sector, whether at Vale-Inco in Sudbury or at US Steel in Hamilton, continue endlessly as employers refuse to bargain with unions in a calculated strategy to wear workers down. In the face of these challenges, workers and their allies have been organizing through innovative union campaigns such as SEIU's Justice for Janitors and UNITE HERE's Hotel Workers Rising, community-based activism, and political action. Through such efforts, workers seek to halt and reverse the decline in working-class power, protect the social fabric of the welfare state, and reduce the widening gap between the rich and poor. 
The wide-reaching impact of working peoples' struggles against neoliberalism confirms the continuing relevance of Labour Studies as an interdisciplinary and engaged field of study which seeks answers to urgent questions about the quality of worklife, the equality and democracy of our socioeconomic arrangements, and our collective capacities to create a more just society. Labour Studies' vibrancy is also reflected in the continual emergence of new generations of scholars who grapple with such questions, as represented in the most recent New Voices in Labour Studies Conference. On October 15-16, 2010, 100 scholars and movement activists from across North America met at York University to discuss the challenges facing workers and the forms of collective action they have taken to meet such challenges. The twenty-eight panelists, all recent graduates or graduate students of Labour Studies and its related disciplines, explored topics including the feminization of the workforce, the gendered impact of back-to-work legislation, the increased mobility and precarity of labour, and a range of community and workplace organizing initiatives designed to bolster worker power.

The New Voices conference papers contained in this edition of Just Labour showcase emerging voices in the field and explore understudied workers and workplaces, uncovering past and contemporary experiences neglected by established scholarship. The new voices featured here tell us about workers whose gender, politics or organizational / occupational status had previously relegated them to the margins of labour markets, the labour movement, and thus Labour Studies itself. Taken together, the papers demonstrate that labour scholars have become increasingly adept at juggling workers' multiple identities and attuned to the complicated ways in which gender, class, ideology and a number of other social categories intersect to shape workers' experiences. The authors' sophisticated use of oral histories and ethnographic research reveals how non-textual sources can be used to produce rich bodies of new knowledge.

The success of the conference as well as the diversity of the articles presented here demonstrate the continued importance of creating a space to discuss labouroriented work in an interdisciplinary setting that promotes and nurtures junior labour scholars and fosters dialogue with established members and activists in the field. In this regard, the participation of Aziz Choudry, Janet Dassinger, Bryan Evans, Grace-Edward Galabuzi, Kate Laxer, Sonia Singh, Mark Thomas and Steven Tufts as chairs and discussants was invaluable. As the latest in a series of conferences which have previously taken place at Trent (2006), McMaster (2008), and Brock (2009) Universities, the growing participation in the 2010 installment of New Voices signals that the study of labour is hardly passé. Now more than ever, Canada's Labour Studies and labour movement communities need an interdisciplinary space which sustains an ongoing dialogue between different generations of labour scholars and activists. As we write this, plans are underway for the fifth New Voices conference to be held at McGill 
University in Montreal in 2012. We have no doubt that the McGill Conference will be as rewarding and enriching as those that have come before it.

Despite their diversity in subject matter and disciplinary origin-coming from Sociology, Communication Studies, Women's and Gender Studies, Anthropology, Education and History - the papers collected here share several important themes. First, several of them grapple with the implications of the feminization of the workforce which began in the 1960s and which has reshaped work in both the public and private sectors. Whether in services or the extraction industries, the durability of gender-typing that constructs certain kinds of job as appropriate for women (coffee service work, personal support work) or for men (manual labour in the oil sands) is revealed. So too is the use of gendered identities by employers, who manipulate women personal support workers' "ethic of care" or oil sands workers' male "breadwinner" role, to extract labour under conditions that are increasingly harmful to workers' physical and mental health. Along with this attention to the feminization of the labour force comes the need for a gendered analysis of the legislation which governs workplaces, and in particular of coercive legislation which is intended to constrain workers' exercise of their collective power.

Second, several articles expose the precarity inherent in forms of work that have been characterized as "creative", autonomous or relatively economically privileged. Maritimers working in Alberta's oil sands enjoy access to breadwinner wages but face perpetual fears of jobs loss in the face of global fluctuations in oil prices. Workers in industries such as food service enjoy neither the union wages of the Fordist era nor job security. In the face of the neoliberal onslaught, once-secure jobs in the media industry are replaced by poorly-paid part- time work. These essays suggest that intellectuals, manual laborers, skilled and unskilled workers alike need to organize collectively to protect themselves from precarity, while acknowledging that the conditions under which they must do so are difficult.

Third, several of these papers point to the creative ways that workers / working class people are responding to the deterioration in their working and living conditions. This creativity can been seen in media workers' experimentation with new models of collective organization forged in the face of the increasing precarity of their labour. It can also be seen in continuing care workers' development of transformative and arts-based pedagogies that reveal both their implication in workplace power inequalities and create the basis for collective analysis and power to resist health care restructuring. Housing activists' community-based attempts to interrupt market-based logic by engaging in collective reappropriation and de-alienation of public spaces represent yet another example of this creativity. The attention to "new" (or at least underattended) workers and strategies challenges the labour movement to expand its 
scope and develop capacities to meet the evolving needs of a changing workforce.

In their article on coffee shop workers, Julia Woodhall and Alicja Muszynski challenge us to reject the overly simplistic dichotomy between Fordist production regimes characterized by high levels of managerial control, standardized work routines, and the deskilling of labour, and post-Fordist ones that rely on more flexible forms of production and labour. Through the use of interviews and ethnographic research in a large Canadian coffee chain, the authors show how Fordist principles have been transplanted to a low-wage service industry characterized by a largely female, part-time, precarious and poorly-paid workforce. Perceived as innately suited to tasks such as food preparation and customer service, women have been recruited to fill the low wage service jobs of the $21^{\text {st }}$ century. However, despite claims that post-Fordist work transcends the alienating nature of the assembly line, coffee shop workers continue to confront components of Fordist organization-via close surveillance of their work and the standardization and routinization of both food preparation and customer service-without enjoying the union protection or union wages of the mass production era. As Woodhall and Muszynski conclude, service workers today "experience the worst of both the Fordist and the post-Fordist models." Their thought-provoking study sheds light on the oppressive conditions of service work confronted by women workers and draws important parallels between Fordist production regimes of the mid-20th century and service work in the early $21^{\text {st }}$ century.

Given Canadian federal and provincial governments' increased use of backto-work legislation since the 1980s and in the recent examples mentioned above, Hans Rollman's call for a gendered analysis of such legislation is both timely and important. While labour scholars have duly noted restrictive legislation's negative impact on workers' collective bargaining rights and trade union freedoms, Rollman's two case studies - one involving legislation passed by the Newfoundland and Labrador government to force 20,000 public sector employees back to work in 2004, and another analyzing the impact of the Educational Accountability Act passed in 2000 by the Ontario governmentsuggest this legislation disproportionately affects women workers. The government-imposed settlement forced on Newfoundland and Labrador's public sector workers targeted and reduced benefits predominantly accessed by women employees, thereby maintaining and increasing existing gender inequalities. By making previously voluntary activities mandatory, Ontario's Educational Accountability Act also adversely affected women teachers who, due to the persistence of traditional gender expectations that define care work for children, elders and sick family members as a female responsibility, suffer the most from legislation that restricts their ability to regulate the degree and timing of their extra-curricular activities. Rollman argues that, while all workers suffer from 
coercive back-to-work and other restrictive legislation, unionized women workers are especially imperiled, as are the gender equality gains that have been or could be made through collective bargaining. Rollman's study has implications for union strategy: if women are disproportionately affected by back-to-work legislation, unions can and should emphasize this gender disparity in their responses to such legislation.

Elizabeth Quinlan explores the workplace experiences of another group of understudied workers, the predominantly female Continuing Care Assistants (CCAs) who provide care to the elderly and infirm in both institutionalized and home-based settings. Quinlan explores the way that neoliberal health care restructuring has created impossible situations for CCAs as they attempt to care for their clients, and fostered increased rates of workplace bullying. In her challenge to the dominant public policy understanding of bullying as a product of individual personality problems, Quinlan makes the case for recognizing the structural bases of bullying as located in neoliberal managerial imperatives and work practices. Quinlan also documents the use of Theatre of the Oppressed methods, which "enable groups to imaginatively shape the world they wish to occupy and become protagonists of their own lives", in anti-bullying workshops for CCAs. Such methods result in a much deeper analysis of both the structural causes of bullying and foster the collective solidarity and capacity of workers to challenge the structures which divide them from each other.

In his article on labour migration between Alberta's oil sands and industrial Cape Breton, Nelson Ferguson demonstrates how workers have used their skillbased mobility to adapt to the Atlantic Provinces' depressed economies. Industrial Cape Breton, the focus of the study, has become a largely remittancebased economy dependent on the regular migration of mostly middle-aged men to the oil sands. Noting the circular nature of this migration-the men take temporary jobs in Alberta that allow them to return home to their families Ferguson studies its impact on both the sending and receiving locales. His interviews and ethnographic research uncover workers who are deeply embedded in social networks, and whose decisions are shaped by their commitments to family and community. His poignant interviews depict the emotional toll that migration takes on workers' families and local communities, and the increasingly precarious nature of this work, but also reveal the benefits that come from securing jobs in this relatively highly paid industry. Like other papers in this collection, Ferguson's study uncovers a gendered component to this work. While most of the oil sands workers are men, the work camps where they live provide jobs for women who are hired to perform stereotypically "feminine" tasks such as cooking, cleaning and laundry.

Nicole Cohen explores the various strategies freelance writers have pursued to address their growing job precarity. Cohen documents the transformations within the field of journalism which mirror those in other industries, where once 
stable and highly remunerated jobs have been replaced with precarious, lowpaid, and even unpaid positions. In discussing the challenges faced by the growing number of freelance magazine writers in Canada, Cohen examines the intersection between writers' occupational identities (as professionals, artists, and individual entrepreneurs), the individualizing and fragmented structure of their work, and the neoliberal ideologies deployed by employers and governments to dismantle the legitimacy of collective worker action. Despite these barriers to organizing, Cohen points to and assesses the potential of the array of organizational forms being developed by freelancers, including the professional association model, unionization and an agency-union partnership.

Joseph Sawan turns our attention to working-class community-based organizing in order to explore the prospects of social movement activity for revealing and countering the effects of alienation prevalent in capitalist societies. Through an engagement with Marx's theory of alienation and Cultural Historical Activity Theory, and their application to a case study of anti-poverty housing activists in a Toronto community, Sawan makes the case that the particular form of social movement activity is crucial to whether it reproduces alienation or provides the basis for de-alienating processes. In particular, Sawan points to the importance of strategies that challenge the valuation of places and people in terms of exchange-value and instead insists on use-values - "building community, mutual support, social justice" - as the dominant criteria for activities that transform the community.

Jason Russell's history of the role of an important left-wing activist in the development of UAW/CAW Local 27 in London, Ontario in the 1950s and 1960s raises important questions about how official memory can erase the important contributions of individuals as well as the strategic alternatives they represent. By supplementing the official union record with an extensive set of oral history interviews, Russell is able to show how Communists such as Al Campbell helped sustain vibrant local union cultures and pursue progressive and largely unpopular goals such as gender equality. The respect and admiration that Campbell commanded from his co-workers, and their unwillingness to succumb to the anti-communism of their famous president Walter Reuther, is a testament to Campbell's extraordinary trade union skills and deep commitment to working-class solidarity.

The works contained in this edition of $J L$ demonstrate the capacities of workers like Campbell to respond to adverse conditions - whether they be the anti-communism of the post-war era or the neoliberalism of the late $20^{\text {th }}$ and early $21^{\text {st }}$ centuries. While militant trade unionists no longer face the spectre of purges under the guise of anti-communism, workers today must grapple with the realities of a labour market where precarious work is increasingly becoming the norm; a government that does not hesitate to use back-to-work legislation to curtail collective bargaining rights and trade union freedoms; employers who 
continue to manipulate gender ideologies as they attempt to justify discriminatory behavior; and neoliberal attacks on workers' communities and families. But as in the Cold War era, workers and their allies continue to organize: in the workplace, in unions and around community issues. No less significantly, workers and trade unionists continue to be at the forefront of social justice efforts to secure racial and gender equality in the workplace and larger society. As such, they must remain the focus of our study and support.

\section{ACKNOWLEDGEMENTS}

In addition to the authors of the articles presented here, we would like to thank the following for making the conference and the production of this special issue of Just Labour possible. We are grateful for the financial support of the Labour College of Canada (Canadian Labour Congress); at York University, the Associate Dean, Research of the Faculty of Liberal Arts and Professional Studies, Professor Leo Panitch (Canada Research Chair on Comparative Political Economy), the Graduate Program in Social and Political Thought and the Department of Geography; and at Ryerson University, the Dean of Arts, the Department of History, the Vice-President of Research and Innovation, and the Centre for Labour Management Relations. As the Conference Organizing Committee's graduate assistant, Simon Black provided invaluable organizational, logistical, and decorative support with good humour and seeming effortlessness. Undergraduate students from the Work and Labour Studies Program at York University, namely Rajbir Kaur, Ann Kim, Supriya Latchman, and Jaspinder Randhawa provided crucial support during the two days of the conference. Thanks to Norene Pupo, long-time editor of Just Labour, for giving another New Voices conference space in the journal, and especially JL editorial assistant Jason Aprile for his amazing editorial, organizational and moral support. Finally, our deep gratitude goes out to Mark Thomas and Steven Tufts, as conference co-organizers and members of the editorial committee for this issue, as well as being the originators of the New Voices conference series. 